\title{
Food manipulation and selection in the omnivorous grapsoid crab Neohelice granulata (Decapoda: Varunidae)
}

\author{
Juan Pablo Lancia, Claudia Bas, Eduardo Spivak
}

\begin{abstract}
Departamento de Biología e Instituto de Investigaciones Marinas y Costeras (IIMyC), Facultad de Ciencias Exactas y Naturales, Universidad Nacional de Mar del Plata, Consejo Nacional de Investigaciones Científicas y Técnicas (CONICET), Casilla de Correo 1260, 7600, Mar del Plata, Argentina. E-mail: jplancia@mdp.edu.ar
\end{abstract}

\begin{abstract}
Summary: Neohelice granulata is an omnivorous, semi-terrestrial burrowing crab endemic to southwestern Atlantic saltmarshes that behaves as a herbivore when it inhabits vegetated saltmarsh areas or a deposit feeder on bare mudflats. In order to gain insights into how non-specialized crabs manage to rely on low quality diets, we studied in laboratory i) how they use feeding appendages to manipulate the food items commonly eaten (halophytic plant leaves and sediment), and ii) their ability to sort particles when they act as deposit feeders by analysing the food particle content of sediment and stomach. According to the source of food consumed, different behaviours and mouthparts involved in food processing were observed. Sex differences were found in handling halophytic plant leaves in the herbivore feeding mode. In deposit feeding, a concentration of potentially N-rich items of animal origin was detected in stomach contents. Indirect evidence of food item concentration from sediment was revealed by analysis of the $\mathrm{C}$ and $\mathrm{N}$ content of sediment and feces. $N$. granulata seems to be an effective deposit feeder even though it lacks the characteristic mouthparts commonly associated with this type of food source.
\end{abstract}

Keywords: crabs; deposit feeding; Neohelice granulata; feeding appendages; feeding mechanisms; food selection; omnivory.

Manipulación y selección del alimento en el cangrejo grapsoideo omnívoro Neohelice granulata (Decapoda: Varunidae)

Resumen: Neohelice granulata es un cangrejo semiterrestre cavador y omnívoro, endémico de las marismas del Atlántico sudoccidental. Se comporta como herbívoro cuando habita en áreas con vegetación halófila y como sedimentívoro cuando habita en llanuras fangosas. Se estudiaron en el laboratorio dos aspectos del comportamiento alimentario de este cangrejo para comprender cómo logra mantenerse en base a dietas de baja calidad: i) la manera en que usa los apéndices bucales para manipular los diferentes tipos de alimento comúnmente consumidos en cada hábitat (hojas de plantas halófitas y sedimento), y ii) su habilidad para seleccionar partículas cuando se alimenta de fango, comparando la composición de las partículas alimenticias presentes en el estómago y en el sedimento. Los cangrejos utilizaron diferentes piezas bucales y tuvieron distintos comportamientos de acuerdo al tipo de alimento consumido. Además, la manipulación de las hojas de plantas halófitas difirió entre sexos. El contenido estomacal de los cangrejos alimentados con fango mostró una mayor concentración de partículas ricas en $\mathrm{N}$ que el sedimento. El análisis del contenido de $\mathrm{C}$ y N del sedimento y las heces evidenció además la capacidad de selección de partículas nutritivas. $N$. granulata puede ser un sedimentívoro eficiente aunque sus piezas bucales no posean las características comúnmente asociadas al consumo de este tipo de alimento.

Palabras clave: Cangrejos; alimentación de depósitos; Neohelice granulata; apéndices bucales; mecanismos de alimentación; selección del alimento; omnivoría.

Citation/Como citar este artículo: Lancia J.P., Bas C., Spivak E. 2014. Food manipulation and selection in the omnivorous grapsoid crab Neohelice granulata (Decapoda: Varunidae). Sci. Mar. 78(4): 529-536. doi: http://dx.doi.org/10.3989/ scimar.04036.02B

\section{Editor: J.E. Cartes.}

Received: February 12, 2014. Accepted: September 10, 2014. Published: October 3, 2014.

Copyright: ( 2014 CSIC. This is an open-access article distributed under the Creative Commons Attribution-Non Commercial Lisence (by-nc) Spain 3.0. 


\section{INTRODUCTION}

Crabs are predominantly omnivores, and extreme feeding specializations are rare. However, a tendency towards particular diets is common and, in the natural environment, there are species that can be considered mainly herbivores (feeding on algae, vascular plants and their detritus), carnivores or scavengers. Foraging strategies can also vary from direct capture and ingestion to deposit feeding and, seldom, to filter feeding (Warner 1977). Many terrestrial and semi-terrestrial crabs are primarily herbivorous although they may act as non-specialized predators or eat carrion whenever possible; others are deposit feeders that rely on fine organic particles, algae, small organisms and bacteria in intertidal sediments (Wolcott and O'Connor 1992, Linton and Greenaway 2007, Sayão-Aguiar et al. 2012). Although uncommon, some species combine different feeding modes. For example, Armases cinereum (Sesarmidae), an estuarine crab, ingests live plants of Spartina spp. in the higher intertidal and supratidal but acts as a deposit feeder and predator in the lower intertidal, selectively picking up detritus and small organisms from the substrate (Seiple and Salmon 1982, Buck et al. 2003).

Crab species that feed to a greater or lesser extent on plants or their detritus and those that are deposit feeders rely on very poor sources of nutrients $(0.7 \%$ to $5 \%$ of plant dry weight corresponds to protein and more than $95 \%$ of sediment used as food is inert material; Mattson 1980, Lopez and Levinton 1987). Consequently, they need to supplement their diets by consuming preferentially energy-rich plant parts such as fruits and seeds or occasionally ingesting animal tissues (Wilde et al. 2004, Linton and Greenaway 2007).

In deposit feeders, there is probably no completely non-selective species and one consequence of such selective ingestion is that feces can be enriched in food value over the ambient sediment despite significant digestion (Lopez and Levinton 1987).

The feeding mode of Neohelice granulata (Varunidae), a semi-terrestrial crab endemic to southwestern Atlantic saltmarshes, varies according to habitat. It is primarily a herbivore when it burrows in saltmarshes, consuming fresh leaves of halophytic grasses (Spartina spp.), but it changes to deposit feeding if it inhabits mudflats, where it scrapes and consumes the surface sediment (Iribarne et al. 1997, Bas et al. 2013). When $N$. granulata behaves as a herbivore, stomach content consists mainly of plant remains; when it behaves as a deposit feeder, it consists largely of inert material, with remains of crustaceans, meiofaunal organisms and plant detritus (D'Incao et al. 1990). Feeding is restricted to certain periods, determined by a complex combination of physical and biological factors (Bas et al. 2013). Mudflats inhabited by $N$. granulata commonly contain very fine sediments (Spivak et al. 1994) that are probably difficult to handle. Specialized structures related to particle assortment have not been described and it is unknown whether this species selects, to some extent, food particles from the sediment it consumes, as do many species of semi-terrestrial ocypodids, including the coexisting Uca uruguayensis (Spivak 1997, SayãoAguiar et al. 2012).

The aim of this study was to investigate the feeding mechanism of $N$. granulata, in order to gain insights into how non-specialized crabs manage to rely on lowquality diets. We expected to find different behaviours and mouthpart usage according to the source of food consumed. To examine this hypothesis, we experimentally studied in aquaria how feeding appendages are used to manipulate the different food items commonly eaten by crabs, and evaluated the ability of crabs to sort particles when they act as deposit feeders.

\section{MATERIALS AND METHODS}

\section{Crab and food collection}

Crabs were collected at Mar Chiquita coastal lagoon, Argentina $\left(37^{\circ} 35^{\prime} \mathrm{S}, 57^{\circ} 26^{\prime} \mathrm{W}\right)$, a brackish water body affected by low-amplitude tides (Spivak et al. 1994). The coast of this lagoon is characterized by a salt marsh in the upper intertidal zone, dominated by halophyte vegetation (Spartina densiflora and Sarcocornia perennis) (Isacch et al. 2006), and a bare mudflat in the middle and low intertidal zones. Crabs occupy the upper and middle intertidal zone (Luppi et al. 2013). Adult males with a 26-32 $\mathrm{mm}$ carapace width (CW) and females with a 21-26 mm CW were captured by hand from burrows at low tide and immediately taken to the laboratory, placed in 50-L aquaria (23\% salinity, $20^{\circ} \mathrm{C}$ and $12: 12 \mathrm{~h}$ light-darkness photoperiod) and deprived of food for three days to favour foraging behaviour and ensure stomach emptiness before the start of experiments.

Two food sources were used in the experiments: sediment and leaves of $S$. densiflora. Sediment was obtained from the same mudflat where the crabs were caught, by scraping the surface layer of soil $(5 \mathrm{~mm}$ thickness) that is commonly removed by crabs during feeding (Lancia pers. obs.). This layer contains algae and microorganisms deposited by water at high tide and part of the soil fauna. Portions of approximately $500 \mathrm{~g}$ were individually stored in bags. Green leaves of $S$. densiflora were randomly cut with scissors from different plants of the saltmarsh. Food was frozen $\left(-20^{\circ} \mathrm{C}\right)$, and defrosted only when feeding experiments were performed.

\section{Use and structure of mouthparts}

To observe the use of feeding appendages when they were feeding on sediments or on leaves, male and female crabs were kept individually in a rectangular glass aquarium $(15 \times 20 \times 15 \mathrm{~cm})$ and fed with the corresponding type of food. Each item was offered differently in order to reproduce natural conditions that ensure feeding behaviour (Lancia et al. 2012). Filming was done with a Nikon Coolpix L22 camera from several angles. Videos length was variable depending on the time expended by crabs in feeding. Recording started when crabs initiated food manipulation and finished when they changed activity some minutes later. The 
observation of different appendages was supplemented by the dissection, observation and measuring of setae of each one in preserved specimens (between 21.8 and $32.1 \mathrm{~mm} \mathrm{CW}$ ) under a stereo microscope. Additionally, maxilliped 2 was mounted on specimen stubs, coated with gold-palladium in a Denton Vacuum Desk II coating unit, and examined in a JSM-6460 scanning electron microscope at $15 \mathrm{Kv}$ accelerating voltage (Laboratorio de Microscopía, Universidad Nacional de Mar del Plata).

\section{Sediment sorting}

Two approaches were used to evaluate the ability of $N$. granulata to select food particles from sediment: 1) the quantification and identification of food particles both in the sediment offered and in stomach contents immediately after feeding, and 2) the determination of the elemental composition ( $\mathrm{C}$ and $\mathrm{N}$ content) of sediment and feces produced after feeding.

Twenty males and 20 females identified with a number on the carapace were fed in groups of five and observed while eating with a video camera. Every sediment portion used for each group of crabs tested was homogenized and moistened. Three samples $(0.2$ $\mathrm{mL}$ each) were taken before offering them to crabs in plastic dishes inside aquaria without water. Wet weight of each sample was determined with an analytical balance $(0.01 \mathrm{mg})$ after draining the excess water with absorbent paper. The sample was then preserved with $4 \%$ formalin and dyed with Bengal rose for one day to visualize and separate organisms or their remains.

After a feeding period of one hour all specimens were cryoanesthetized and rapidly killed by introducing forceps ventrally in the cephalothorax. The carapace was dorsally opened; the stomach was removed with forceps and its content was drained, weighed and preserved as sediment samples. Individuals that had not completed at least half of their stomach volume were discarded.

Sediment samples and stomach contents were resuspended in water, homogenized and placed in 1-mL aliquots into a Sedgewick Rafter counting chamber to be examined under microscope with $4 \times$ magnification. The content of 40 uniformly distributed cells was counted and classified and then the corresponding number for each aliquot was estimated.

Organisms or their remains were classified into the following categories: diatoms, crustaceans (ostracod, copepod or decapod remains), Foraminifera, Nematoda, Polychaeta and $S$. densiflora fragments. The range and average size for organisms were estimated by measuring the long axis or diameter of individuals randomly selected belonging to each category from every aliquot analysed. The number of individuals of each category for the entire volume of each sample (all aliquots summed) was expressed per gram of sample. Only organisms or their remains larger than $0.08 \mathrm{~mm}$ were considered.

An electivity index of food (L) (Strauss 1979) was calculated as:

$$
\mathrm{L}=\mathrm{r}_{\mathrm{i}}-\mathrm{p}_{\mathrm{i}}
$$

where $r_{i}$ and $p_{i}$ are the relative abundances (expressed as percentages) of prey item $\mathrm{i}$ in stomach and habitat, respectively. $L$ takes values between -1 and 1 , where 0 is the expected value for random feeding (no selection), and values close to 1 and -1 mean that prey is very rare but consumed exclusively or that prey is abundant but rarely consumed.

\section{Elemental composition of food and feces}

This estimation is based on the common method of determination of assimilation efficiency, in which the difference in every organic component between food and feces corresponds to the proportion of each component assimilated by individuals (the contribution made by peritrophic membranes to feces content is commonly negligible in assimilation estimations, see references in Linton and Greenaway 2007). However, if individuals are able to select organic components from offered food, the result may be a higher content of them (mainly carbon and nitrogen) in feces than in food (Lopez and Levinton 1987).

To compare $\mathrm{C}$ and $\mathrm{N}$ contents of diet and feces, five samples were taken from a homogenized sediment portion before it was given as food to five $N$. granulata females, and these samples placed in pre-weighed aluminum capsules. After feeding, females were placed in individual plastic boxes and their feces were collected and placed in pre-weighed aluminum capsules (three replicates per female). All samples were immediately frozen $\left(-20^{\circ} \mathrm{C}\right)$ and lyophilized until analysis once all the material had been obtained. Since Mar Chiquita sediment has high amounts of $\mathrm{C}$ in inorganic form (as carbonate), which interferes with the estimate of organic $\mathrm{C}$, the only one of interest in this case, it had to be previously eliminated by treating the samples with sulphurous acid according to Verardo et al. (1990). Elemental composition was measured by a microanalyser (Thermo Finnigan Flash EA 1112). Results were expressed as $\mu \mathrm{g}$ of $\mathrm{N}$ and $\mathrm{C}$ per mg of sample.

\section{Statistical analysis}

The number of organisms of each taxonomical category ingested was compared between stomach contents and the corresponding sediment sample with paired t-test. Size of food categories was compared between sediment and stomach by t-tests. Sex differences in calculated electivity indexes were analysed with a t-test. $\mathrm{N}$ and $\mathrm{C}$ contents were compared with one-way ANOVA. All data were checked for normality and homoscedasticity. In all cases, significance was set at $\mathrm{p}<0.05$ (Sokal and Rohlf 1979).

\section{RESULTS}

\section{Use of mouthparts during plant and deposit feeding}

From direct observation and recordings of male and female crab feeding behaviour, differences in handling $S$. densiflora leaves were detected. All observed fe- 
males, and young males of size similar to larger females (about $26 \mathrm{~mm} \mathrm{CW}$ ), separated the longitudinal strands or fibers of a leaf with their chelae and cut a thin strand with their mandibles. Larger males, instead, used their chelae to bend the entire leaf before cutting it along the fold with their mandibles, handling the resulting piece with both chelae. The subsequent phase of fractioning and ingestion was similar in both sexes. The dactylus of third maxilliped was used to hold and guide the cut pieces (either a long thin strand or a whole piece of leaf according to sex and size) into the mouth. Food was skillfully manipulated by the dactylus of second maxilliped and processed by mandibles; finally the small sectioned pieces were ingested.

When the crabs were feeding on sediment, no differences were observed between sexes either in the appendices involved or in the way they were used. Each individual roamed through the area, occasionally introducing its chelae into the sediment and carrying some mud into the mouth in an apparent assessment activity. During this raking, crabs sometimes found larger items (mainly plant detritus), which they took between propodus and dactylus before carrying them to the mouth. Otherwise, they eventually stopped in a given area and ingested the sediment present using one or both chelae alternately as spoons to take sediment into the mouth. Third maxillipeds were not used in food manipulation and remained open. In contrast, dactyls of second maxillipeds actively pushed and manipulated the sediment obtained by chelae to ingest it or helped to expel undesirable portions (mainly shell remains or plastic debris). Activity of maxillules, maxilles and first maxillipeds was not evident during feeding on sediment.

\section{Structure of mouthparts}

Setation patterns of mandibles and second maxillipeds, the only two mouthparts actively used to process food during feeding on both types of food, are described following Lavalli and Factor (1995).
Mandible: as usual, setation is only present at the mandibular palp. The distalmost segment has a dense brush of short simple setae of different thickness on the inner edge, and longer pappose setae on the opposite edge. The basal and middle segments bear tufts of very long plumose setae.

Maxilliped 2: ischium exhibits a tuft of long plumose setae on the inner edge; merus has long pappose setae (Fig. 1, $p_{1}$ ), with fine denticulations at the tip, on the inner edge and scattered long pappose setae (Fig. $1, \mathrm{p}_{2}$ ) with sparsely arranged setules on the surface. Carpus is almost naked, bearing only some sparse simple setae (Fig. 1, $\mathrm{s}_{1}$ ); propodus bears long simple setae (Fig. 1, $\mathrm{s}_{2}$ ) at both sides and very short, robust (length/ width ratio about 3.5; Fig. 1, sr) setae on the surface. Dactylus has pappose setae (Fig. 1, $\mathrm{p}_{3}$ ) with sparse, short setules arranged along the shaft, and small setae on the surface, similar to those on propodus (Fig. 1, sr). Additionally, a belt of cuspidate setae line up along the edge (Fig. 1, c), becoming shorter and thicker towards the distal part of the dactylus, where they form a comb. The average size of comb setae is $0.26 \pm 0.09 \mathrm{~mm}$ and the distance between them is $0.06 \pm 0.02 \mathrm{~mm}$. They show signs of wear, especially those from the centre (Fig. 1, right).

\section{Food selection in deposit feeding}

The stomach content of 8 males and 5 females was analysed; the remaining 12 males and 15 females used in the experiment did not feed or did not reach a stomach fullness volume $\geq 50 \%$, so they were discarded.

Organisms and their relative proportions were similar among different sediment samples but total density varied. Diatoms were always the most abundant category, reaching values between 1261 and 14690 individuals/g of sample, with an average proportion of $0.65 \pm 0.11$ (Fig. 2). Three other items followed diatoms in importance: crustaceans, mainly ostracods and copepods (0 to 3609 individuals/g of sample and average proportion of $0.1 \pm 0.05$ ), nematodes (200 to 2287

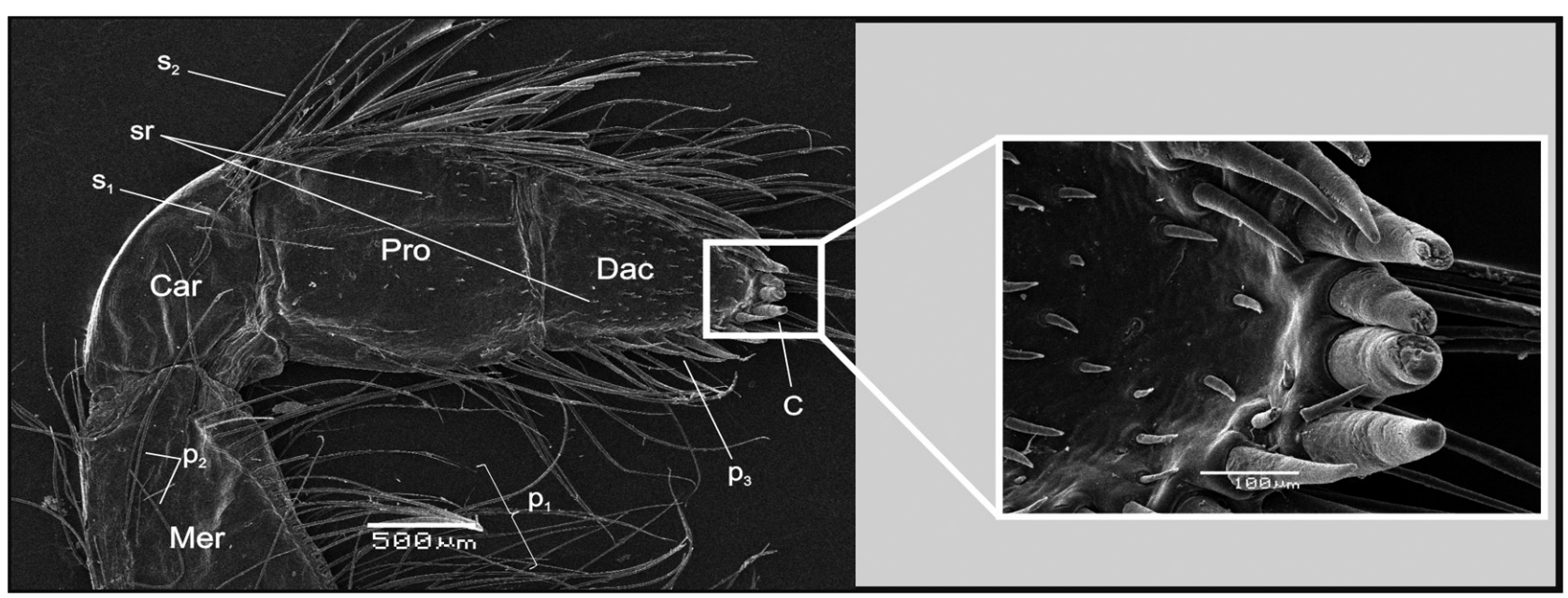

Fig. 1. - Neohelice granulata. SEM photomicrographs of maxilliped 2. Right, detail of cuspidate setae at the distal part of the dactylus showing signs of worn. Mer, merus; Car, carpus; Pro, propodus; Dac, dactylus; $\mathrm{p}_{1}$, long pappose setae; $\mathrm{p}_{2}$, scattered long pappose setae; $\mathrm{s}_{1}$, sparse simple setae; $\mathrm{s}_{2}$, long simple setae, sr, small and robust setae; $\mathrm{p}_{3}$, pappose setae; c, cuspidate setae. 


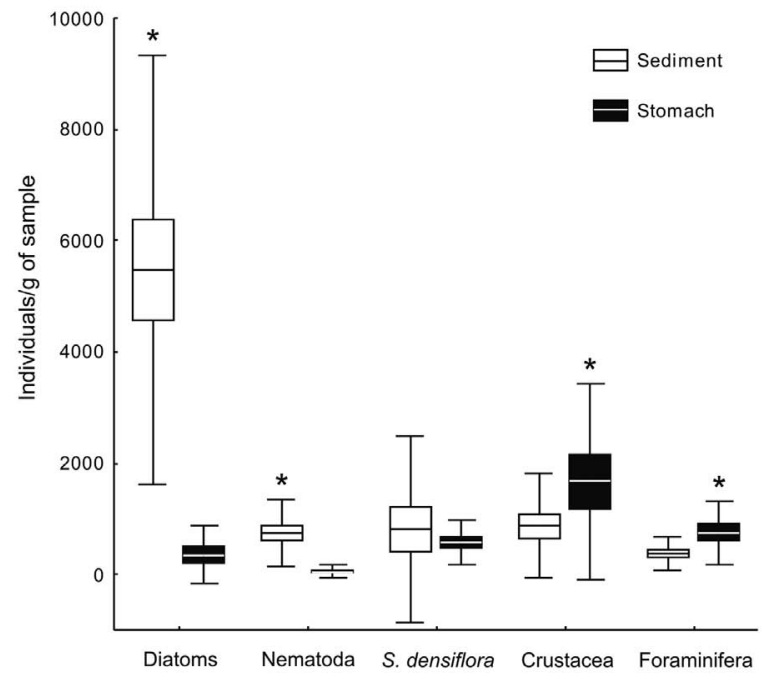

Fig. 2. - Neohelice granulata. Number of organisms or their remains present in sediment used as food and in stomachs after deposit feeding. Horizontal line in box, mean; box, mean \pm standard error; whiskers, mean \pm standard deviation. Asterisks indicate significant greater values (paired t-test, $\mathrm{p}<0.05$ ).

individuals $/ g$ of sample, $0.09 \pm 0.01)$, remains of $S$. densiflora (0 to 6642 particles/g of sample, $0.09 \pm 0.14$ ) and foraminifers 0 to 1050 individuals/g of sample, $0.07 \pm 0.06$ (Fig. 2). Setae and mandibles of polychaetes were present in 5 of the 7 sediment fractions analysed with an average proportion of $0.01 \pm 0.01$ particles/g of sediment (not shown).

In all the stomachs analysed, the same categories were always present, excepting polychaete remains, which appeared in only 4 of the 13 stomachs, with a maximum proportion of 0.06 , so they were not considered for the final analysis. There were differences between sediment and stomach contents in the number of items and their respective proportions for most of the defined categories. Diatom and nematode concentrations were lower in stomachs than in sediment (0 to 1901 and 0 to 365 individuals/g of sample and $0.11 \pm 0.09$ and $0.02 \pm 0.05$ of average proportion respectively, paired t-test, $\mathrm{p}<0.001$ both cases). Crustaceans and foraminifers, instead, were higher in stomach content than in sediment (360 to 5702 and 0 to 1990 individuals/g of sample and $0.46 \pm 0.17$ and $0.2 \pm 0.16$ of average proportion respectively, paired t-test, $\mathrm{p}=0.012$ and 0.03 respectively) (Fig. 2). S. densiflora remains ( 0 to 1425 individuals/g of sample and $0.19 \pm 0.12$ average proportion) did not differ from sediment content (paired t-test, $\mathrm{p}=0.343$ ).

Average size of each food category was the same for sediment or stomach samples (t-test, $\mathrm{p}>0.05$ in all cases) and is summarized in Table 1. Diatoms smaller than $0.08 \mathrm{~mm}$ were abundant but not considered in the counting since they were in the limit of the aperture let by setae, so they were not expected to be actively
Table 1. - Neohelice granulata. Size range and average of food categories found in sediment and stomach samples after deposit feeding

\begin{tabular}{lcc}
\hline Food category & Size range $(\mathrm{mm})$ & Size average $(\mathrm{mm})$ \\
\hline Diatoms & $0.08-0.28$ & 0.15 \\
Nematoda & $0.24-1.68$ & 0.67 \\
S. densiflora & $0.2-4.72$ & 0.78 \\
Crustacea & $0.08-0.33$ & 0.21 \\
Foraminifera & $0.4-0.8$ & 0.57 \\
\hline
\end{tabular}

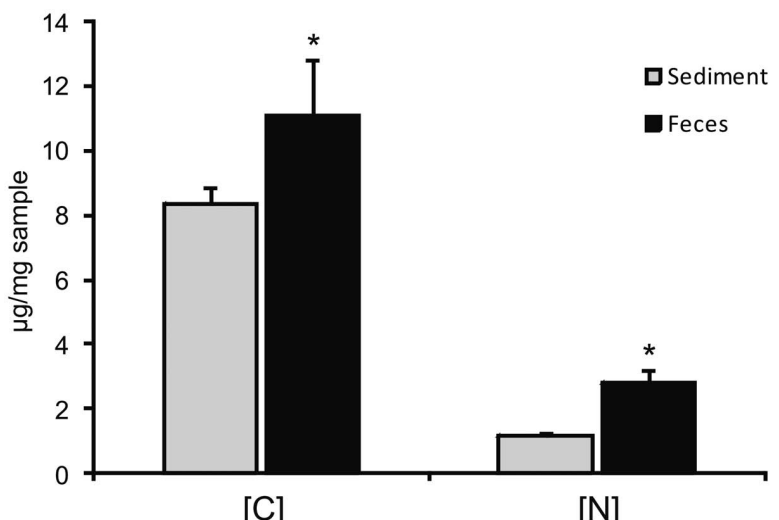

[C]

[N]

Fig. 3. - Neohelice granulata. $\mathrm{C}$ and $\mathrm{N}$ concentration $(\mu \mathrm{g} / \mathrm{mg})$ in sediment used as food and in stomachs after deposit feeding. Asterisks indicate significant greater values (ANOVA, $\mathrm{p}<0.05$ ).

selected. No individuals of the other categories or their remains below that size limit were observed.

There were no significant differences for electivity indices between sexes (t-test, $\mathrm{p}>0.05$ in all cases) and data were pooled. This lack of differences should be taken cautiously since the number of individuals and therefore the power of tests to detect differences were low. However, in accordance with test results, no variations in mouthparts between sexes were observed. The highest indexes corresponded to crustaceans, followed by foraminifers. Electivity for diatoms was clearly negative, while those for Nematoda and remains of $S$. densiflora were close to zero (Table 2).

\section{Elemental composition of food and feces in deposit feeding}

Organic C content estimated from sediment $(8.4 \pm 0.51 \mu \mathrm{g} / \mathrm{mg})$ was lower than in feces $(11.09 \pm 1.72$ $\mu \mathrm{g} / \mathrm{mg}$ ) (ANOVA, $\mathrm{p}=0.007$ ) and the same was true with the estimated $\mathrm{N}$ content $(1.16 \pm 0.07$ and $2.79 \pm 0.43$ $\mu \mathrm{g} / \mathrm{mg}$ for sediment and feces, respectively) (ANOVA, $\mathrm{p}<0.001$ ) (Fig. 3).

\section{DISCUSSION}

The great complexity of feeding apparatus in decapods, which includes mandibles, maxillules and maxillae as in other crustaceans, plus three pairs of maxillipeds,

Table 2. - Neohelice granulata. Electivity indices for each food item present in the sediment after deposit feeding. Negative values indicate avoidance or inaccessibility, values close to zero, random feeding and positive values, preferably.

\begin{tabular}{lcccc}
\hline & Diatoms & Nematoda & S. densiflora & Foraminifera \\
\hline Average & -0.532 & -0.055 & 0.084 & 0.174 \\
sd & 0.099 & 0.056 & 0.105 & 0.321 \\
\hline
\end{tabular}


and frequently chelae for handling food, has undoubtedly played a vital role in the success of this group, since it has allowed an enormous diversity of feeding modes and resource use (Garm and Høeg 2001).

Chelae are considered versatile and multifunctional organs used for food manipulation, agonistic interactions, competition for (and manipulation of) females and excavation (Lee and Seed 1992, Negreiros-Fransozo and Fransozo 2003). Sexual dimorphism in chelae is a consequence of their widespread use by male in combat, exhibition and courtship. A difference between sexes was evident regarding the use of chelae for handling $S$. densiflora leaves but the mechanism of sediment collection is the same. Female chelae grow at a lower positive allometric rate than male chelae and are proportionally smaller (Hartnoll 1974). Chela relative size could explain the observed differences in handling leaves between sexes and within males of different sizes. The largest chelae are usually equipped with strong muscles capable of applying large leverage forces (Lee 1995), so they can exert stronger forces and bend the whole leaf. This procedure allows large individuals to cut leaves at the bending point with mandibles. Females and smaller males are apparently not able to bend the hard, not very flexible $S$. densiflora leaves and must use a different mechanism to separate portions of leaf: their smaller chelae separate longitudinal strands or fibres of a leaf before cutting them with their mandibles. During feeding on sediment, chelae are used as spoons to carry sediment to the mouth and no particular force is involved. Consequently, differences in chela size may affect the amount of sediment that can be brought into the mouth with each movement but not its content.

Mechanical functionality of diverse mouthparts is largely determined by the type and arrangement of setae present in each one (Garm and Høeg 2001). Crabs having the ability of feeding on sediment seem to share the common trait of a great development and diversification of setae in their mouthparts, chelipeds and even walking legs (Sayão-Aguiar et al. 2012). In contrast, even when individuals of $N$. granulata act almost exclusively as deposit feeders when they burrow in mudflat areas (Bas et al. 2013, Luppi et al. 2013), body surface and legs are almost free of setae, and chelae are naked, with only small tubercles on the surface (Boschi et al. 1992). Second maxillipeds, the most actively used piece in deposit feeding, have conspicuous setae although they are not especially abundant or diversified. Plumose setae, only present in merus and ischium, are long but not very densely arranged; dactylus bears scarce papposae and simple setae, usually considered to have no function in food selection (Lavalli and Factor 1995) and cuspidate setae in the distal part of these dactylus. Evident signs of wear in many cuspidate setae of dactyli suggest their active participation in food manipulation. Garm (2005) described the mouthparts that are in direct contact with food during prey manipulation of Carcinus maenas. He found that maxillipeds 2 and 3 are both very active in food manipulation, holding mechanoreceptors that provide the animal with detailed information about the prey items.
$N$. granulata uses the same appendices to process very different kinds of food. Maxilliped 3 is used in leaf manipulation, while maxilliped 2 is used either in leaf or in sediment processing, appearing to be a very versatile structure. It would be of interest to analyse the use of these appendices when this crab behaves as a predator or cannibal, as it occasionally does (Bas et al. 2013).

The number of diatoms found in stomachs decreased significantly in relation to that in sediment, and the same was true for Nematoda, a potential source of protein that was almost neutrally selected. Although their maximal average size is not very different from that of other recorded items, they can easily be suspended in a water film (Burr and Robinson 2004, Acuña et al. 2010). Since N. granulata feed on water-saturated sediments, part of diatoms and nematods could be washed by the water, escaping from the mesh formed by setae. Crustaceans and Foraminifera, relatively larger in volume and heavier, are clearly selected. Finally, plant detritus, although abundant and large, is only slightly selected, suggesting that not only size but other characteristics such as form could be important.

This species is able to extract from processed sediment some of the high-energy items, enriching the stomach contents two-fold in crustaceans and foraminifers. In accordance, a higher $\mathrm{C}$ and $\mathrm{N}$ content observed in $N$. granulata feces, compared with sediment given as food, is additional evidence that the organic matter effectively ingested was more than the average in bulk sediment. However, it is probable that the degree to which this crab selects each item changes under diverse conditions. Food selection by different crabs has been proved to be affected by numerous factors, such as the type of food eaten previously (Thacker 1998), the food combination offered (Mchenga and Tsuchiya 2010) or a previous starvation period (Brousseau and Baglivo 2005). Then, the ability for selecting some items from the available natural offer and the ability of choosing the best combination in each situation may allow crabs to optimize the ingestion in a continuously changing scenario.

Though the sediment offered in the experiments was collected in the feeding area of $N$. granulata (mudflat area at Mar Chiquita coastal lagoon), its food content may have not reflected the concentrations actually found by crabs in natural conditions. Since it was homogenized before its use, surface food particles may have been less available. Crabs could find denser patches of food accessible on sediment surface in the field, improving the food accumulation in stomachs. Furthermore, in natural conditions, diets are complemented with fresh plant leaves (those individuals that inhabit the mudflat and feed mainly on sediment consume plants to some extent and vice versa, Bas et al. 2013), and with the occasional consumption of carrion, predation on larger preys such as polychaetes, and cannibalism, (D'Incao et al. 1990, Bas et al. 2013, Lancia 2013).

Behavioural and physiological characteristics of $N$. granulata correspond to generalist or omnivorous animals, given that this species shares some characteristics with pure herbivores and predators. Among the former are the ability to digest cellulose in all its forms (Lancia 
et al. 2012) and a comparatively large stomach volume, filled in some cases exclusively by plants (Bas et al. 2013). Among the latter is the ability to capture and consume live animals (Barbosa and Castellanos 2005). Omnivory, the ability of feeding at multiple trophic levels, is a lifestyle more common than previously thought in many invertebrate and vertebrate species (Eubanks 2005). Diet mixture, wherein the nutritional quality of one type of food (for example plant material) is increased by the intake of another type of food (for example animal material) occurs in many omnivorous species and can strongly enhance their fitness (Sibly 1981).

Neohelice granulata is at present the only crab exploiting marsh environments of the southwest Atlantic, and it is found in all areas where some of the species of the genus Spartina are present (Spivak 1997). The ability of this species to degrade cellulose and feed on vascular plants is presumably associated with its success in colonizing these environments. However, equally important must have been the development of the ability to select energy-rich items from sediment, compensating the limited periods of feeding after each tidal receding (Bas et al. 2013), and allowing them to obtain the necessary complement to an N-low diet.

Finally, it is clear that though $N$. granulata lacks the main morphological characteristics associated with this type of feeding, as small spooned chelae or profuse and diverse setation in feeding appendices and/or body surface (Warner 1977, Schembri 1982), it can be an effective deposit feeder.

\section{ACKNOWLEDGEMENTS}

This work is part of the doctoral thesis of J.P.L. and was supported by a Ph.D. fellowship from the National Research Council of Argentina (CONICET-PIP 176) and the Universidad Nacional de Mar del Plata (EXA $527 / 10)$.

\section{REFERENCES}

Acuña J.L., López-Alvarez M., Nogueira E., et al. 2010. Diatom flotation at the onset of the spring phytoplankton bloom: an in situ experiment. Mar. Ecol. Prog. Ser. 400: 115-125. http://dx.doi.org/10.3354/meps08405

Barbosa P., Castellanos I. 2005. Ecology of predator-prey interactions. Oxford University Press Inc. New York, 413 pp.

Bas C., Lancia J.P., Luppi T., et al. 2013. Influence of tidal regime, diurnal phase, habitat and season on feeding of an intertidal crab. Mar. Ecol. 35: 319-331. http://dx.doi.org/10.1111/maec.12083

Boschi E.E., Fischbach C.E., Iorio M.I. 1992. Catálogo ilustrado de los crustáceos estomatópodos y decápodos marinos de la Argentina. Frente Marino 10(Sec. A): 7-94.

Brousseau D.J., Baglivo J.A. 2005. Laboratory investigations of food selection by the Asian shore crab, Hemigrapsus sanguineus: algal versus animal preference. J. Crustac. Biol. 25(1): 130-134. http://dx.doi.org/10.1651/C-2530

Buck T.L., Breed G.A., Pennings S.C., et al. 2003. Diet choice in an omnivorous salt-marsh crab: different food types, body size, and habitat complexity. J. Exp. Mar. Biol. Ecol. 292: 103-116. http://dx.doi.org/10.1016/S0022-0981(03)00146-1

Burr A.H.J., Robinson A.F. 2004. Locomotion Behaviour. In: Gaugler R., Bilgrami A.L. (eds), Nematode Behaviour. CABI Publishing, Cambridge, pp. 445. http://dx.doi.org/10.1079/9780851998183.0025

D’Incao F., Silva K.G., Ruffino M.L., et al. 1990. Hábito alimentar do caranguejo Chasmagnathus granulata Dana, 1851 na barra do Rio Grande, RS (Decapoda, Grapsidae). Atlantica 12(2): 85-93.

Eubanks M.D. 2005. Predaceous herbivores and herbivorous predators. In: Barbosa P., Castellanos I. (eds), Ecology of predatorprey interactions. Oxford University Press, Inc., New York, pp. 3-16.

Garm A. 2005. Mechanosensory properties of the mouthpart setae of the European shore crab Carcinus maenas. Mar. Biol. 147: 1179-1190. http://dx.doi.org/10.1007/s00227-005-0020-7

Garm A., HØeg J.T. 2001. Function and functional groupings of the complex mouth apparatus of the squat lobsters Munida sarsi Huus and M. tenuimana G.O. Sars (Crustacea: Decapoda). Biol. Bull. 200: 281-297. http://dx.doi.org/10.2307/1543510

Hartnoll R.G. 1974. Variation in growth pattern between some secondary sexual characters in crabs (Decapoda. Brachyura). Crustaceana 27(2): 131-136. http://dx.doi.org/10.1163/156854074X00334

Iribarne O., Bortolus A., Botto F. 1997. Between-habitat differences in burrow characteristics and trophic modes in the southwestern Atlantic burrowing crab Chasmagnathus granulata. Mar. Ecol. Prog. Ser. 155: 137-145. http://dx.doi.org/10.3354/meps155137

Isacch J.P., Costa C. S. B., Rodriguez-Gallego L., et al. 2006. Distribution of saltmarsh plant communities associated with environmental factors along a latitudinal gradient on the south-west Atlantic coast. J. Biogeogr. 33: 888-900. http://dx.doi.org/10.1111/j.1365-2699.2006.01461.x

Lancia J.P. 2013. Ecología y fisiología alimentaria del cangrejo Neohelice granulata. Ph.D. thesis, Universidad Nacional de Mar del Plata, Mar del Plata, 136 pp.

Lancia J.P., Fernández Gimenez A., Bas C., et al. 2012. Adaptive differences in digestive enzyme activity in the crab Neohelice granulata in relation to sex and habitat. J. Crustac. Biol. 32(6): 940-948

http://dx.doi.org/10.1163/1937240X-00002090

Lavalli K.L., Factor R.J. 1995. The feeding appendages. In: Factor R.J. (ed), The Biology of the lobster, Homarus americanus. Academic Press, New York, pp. 349-393. http://dx.doi.org/10.1016/B978-012247570-2/50036-0

Lee S.Y. 1995. Cheliped size and structure: the evolution of a multi-functional decapod organ. J. Exp. Mar. Biol. Ecol. 193: $161-176$. http://dx.doi.org/10.1016/0022-0981(95)00116-6

Lee S.Y., Seed R. 1992. Ecological implications of cheliped size in crabs: some data from Carcinus maenas and Liocarcinus holsatus. Mar. Ecol. Prog. Ser. 84: 151-160. http://dx.doi.org/10.3354/meps084151

Linton S.M., Greenaway P. 2007. A review of feeding and nutrition of herbivorous land crabs: adaptations to low quality plant diets. J. Comp. Physiol. B. 177: 269-286. http://dx.doi.org/10.1007/s00360-006-0138-z

Lopez G.R., Levinton J.S. 1987. Ecology of deposit-feeding animals in marine sediments. Q. Rev. Biol. 62(3): 235-260. http://dx.doi.org/10.1086/415511

Luppi T., Bas C., Méndez Casariego A., et al. 2013. The influence of habitat, season and tidal regime in the activity of the intertidal crab Neohelice (=Chasmagnathus) granulata. Helgoland Mar. Res. 67: 1-15. http://dx.doi.org/10.1007/s10152-012-0300-9

Mattson W.J. 1980. Herbivory in relation to plant nitrogen content. Annu. Rev. Ecol. Syst. 11: 119-161. http://dx.doi.org/10.1146/annurev.es.11.110180.001003

Mchenga I.S.S., Tsuchiya M. 2010. Feeding choice and the fate of organic materials consumed by Sesarma crabs Perisesarma bidens (De Haan) when offered different diets. J. Mar. Biol. 2010. http://dx.doi.org/10.1155/2010/201932

Negreiros-Fransozo M.L., Fransozo V. 2003. A morphometric study of the mud crab, Panopeus austrobesus Williams. 1983 (Decapoda. Brachyura) from a subtropical mangrove in South America. Crustaceana 76(3): 281-294. http://dx.doi.org/10.1163/156854003765911685

Sayão-Aguiar B., Amaro Pinheiro M.A., et al. 2012. Sediment bioturbation potential of Uca rapax and Uca uruguayensis as a result of their feeding activity. J. Crustac. Biol. 32(2): 223-229. http://dx.doi.org/10.1163/193724011X615451

Schembri P.J. 1982. Feeding behaviour of fifteen species of hermit 
crabs (Crustacea: Decapoda: Anomura) from the Otago region, southeastern New Zealand. J. Nat. Hist. 16: 859-878. http://dx.doi.org/10.1080/00222938200770691

Seiple W., Salmon M. 1982. Comparative social behavior of two grapsid crabs, Sesarma reticulatum (Say) and $S$. cinereum (Bosc). J. Exp. Mar. Biol. Ecol. 62: 1-24. http://dx.doi.org/10.1016/0022-0981(82)90213-1

Sibly R.M. 1981. Strategies of digestion and defecation. In: Townsend C.R., Calow P. (eds), Physiological Ecology: an evolutionary approach to resource use. Blackwell Scientific Publications, Oxford, pp. 109-139.

Sokal R., Rohlf J. 1979. Biometría. Principios y métodos estadísticos en la investigación biológica. Blume H., Madrid, 775 pp.

Spivak E.D. 1997. Cangrejos estuariales del Atlántico sudoccidental $\left(25^{\circ}-41^{\circ} \mathrm{S}\right)$ (Crustacea: Decapoda: Brachyura). Invest. Mar. Valparaíso 25: 105-120.

Spivak E., Anger K., Luppi T., Bas C., Ismael D. 1994. Distribution and habitat preferences of two grapsid crab species in Mar Chiquita Lagoon (Province of Buenos Aires, Argentina). Helgol. Meeresunters. 48: 59-78.

http://dx.doi.org/10.1007/BF02366202
Strauss R.E. 1979. Reliability estimates for Ivlev's electivity index, the forage ratio, and a proposed linear index of food selection. Trans. Am. Fish. Soc. 108: 344-352. http://dx.doi.org/10.1577/1548-8659(1979)108<344:REFIEI> 2.0.CO;2

Thacker R.W. 1998. Avoidance of recently eaten foods by land hermit crabs, Coenobita compressus. Anim. Behav. 55: 485-496. http://dx.doi.org/10.1006/anbe.1997.0621

Verardo D.J., Froelich P.N., McIntyre A. 1990. Determination of organic carbon and nitrogen in marine sediments using the Carlo Erba NA-1500 analyzer. Deep-Sea. Res. 37(1): 157-165. http://dx.doi.org/10.1016/0198-0149(90)90034-S

Warner G.F. 1977. The biology of crabs. Van Nostrand Reinhold Company, New York. 202 pp.

Wilde J.E., Linton S.M., Greenaway P. 2004. Dietary assimilation and the digestive strategy of the omnivorous anomuran land crab Birgus latro (Coenobitidae). J. Comp. Physiol. B. 174: 299-308. http://dx.doi.org/10.1007/s00360-004-0415-7

Wolcott D.L., O'Connor N.J. 1992. Herbivory in crabs: Adaptations and ecological considerations. Am. Zool. 32(3): 370-381. 